\title{
Unexpected expression of Orexin-B in basal conditions and increased levels in the adult rat hippocampus during pilocarpine-induced epileptogenesis
}

\author{
Anne Morales, Chantal Bonnet, Naïck Bourgoin, Thierry Touvier, Jérémie Nadam, Aël Laglaine, \\ Fabrice Navarro, Colette Moulin, Béatrice Georges, Jean-Marc Pequignot and Laurent Bezin
}

Laboratoire de Physiologie Intégrative Cellulaire et Moléculaire

UMR 5123 CNRS and Université Claude Bernard Lyon 1, Villeurbanne, France

\begin{abstract}
31 pages
8 figures

1 table
\end{abstract}

Corresponding author: $\quad \operatorname{Dr} A$. Morales

Laboratoire de Physiologie Intégrative Cellulaire et Moléculaire

Université Claude Bernard Lyon 1

43 Bd du 11 Novembre 1918

69622 Villeurbanne Cedex

France

Tel : +33472445841

Fax : +33472431172

Email : morales@univ-lyon1.fr

Abbreviations used: DG, Dentate Gyrus, ICV, intracerebroventricular, IP, intraperitoneal, LH, lateral hypothalamic area, OX, orexin, OXR, orexin receptor, PeF, perifornical nucleus, Pilo-SE, pilocarpineinduced SE, PVT, paraventricular thalamic nucleus, SD, scopolamine-diazepam, SE, status epilepticus, SmRNA, synthetic external and non-homologous poly(A) Standard RNA. 


\section{Abstract, 1.}

Orexin A (OX-A) and B (OX-B) peptides present in the hippocampus are considered to be exclusively contained in fibers arising from hypothalamus neurons, which were established as the only source of orexins (OXs). Because OX-A is known to exert excitatory actions in the hippocampus, we hypothesized that level of OXs targeted toward the hippocampus may be increased following status epilepticus (SE)-induced epileptogenesis in the rat pilocarpine model of temporal lobe epilepsy. We found that tissue concentration of prepro-OX mRNA, which encodes for both peptides, rapidly decreased in the hypothalamus of rats having experienced pilocarpine-induced SE (Pilo-SE), followed by a reduced density of OX-A and OX-B immunopositive fibers arising from these neurons. By contrast, it was unexpected to detect within the hippocampus the presence of prepro-OX mRNA in basal conditions, and to evidence its up-regulation during the 1-3 day period following Pilo-SE. The number of prepro-OX mRNA copies determined by real-time RT-PCR was $\sim 50$-fold lower in the hippocampus than that in the hypothalamus, precluding the use of in situ hybridization to localize the cells which synthesize the transcript within the hippocampus. The increase in prepro-OX mRNA level within the hippocampus was accompanied by the detection of OX-B-like immunoreactivity $2-3$ days post-SE, not only in pyramidal neurons, granule cells and cell bodies resembling interneurons, but also in some astrocytes scattered throughout the hippocampus. The present data suggest that the gene encoding OXs can be activated in the hippocampus, which may play a role in the pathogenesis of epilepsy.

Section: Disease-Related Neuroscience

Keywords: Temporal lobe epilepsy, hypothalamus, prepro-orexin, orexin, hypocretin, astrocytes 


\section{Introduction, 2.}

Orexin-A (OX-A) and orexin-B (OX-B), also known as hypocretin-1 and -2 , are two peptides derived by proteolytic cleavage from a 130 amino acid prepro-OX precursor synthesized within neurons located in the hypothalamus (de Lecea et al., 1998; Peyron et al., 1998; Sakurai et al., 1998). By contrast, OX innervation arising from hypothalamus neurons is highly divergent (Peyron et al., 1998; Date et al., 1999) and G-protein-coupled $\mathrm{OX}$ receptors 1 and $2\left(\mathrm{OX}_{1} \mathrm{R}\right.$ and $\mathrm{OX}_{2} \mathrm{R}$, respectively) are widely distributed throughout the central nervous system (Sakurai et al., 1998; Trivedi et al., 1998; Greco and Shiromani, 2001; Hervieu et al., 2001; Marcus et al., 2001; Cluderay et al., 2002). Therefore, OX system has been recognized as a major regulator of various behavioural activities including feeding (Sakurai et al., 1998; Ida et al., 1999; Yamada et al., 2000), sympathetic nerve activity (Shirasaka et al., 1999) and normal sleep-wake cycle (Chemelli et al., 1999; Hagan et al., 1999) and its dysfunction has clearly been associated with pathophysiological disorders such as the sleep-disorder narcolepsycataplexy (Chemelli et al., 1999; Lin et al., 1999; Nishino et al., 2000; Peyron et al., 2000). Within the hippocampus, $\mathrm{OX}_{1} \mathrm{R}$ and $\mathrm{OX}_{2} \mathrm{R}$ have been specifically detected in $\mathrm{CA} 1, \mathrm{CA} 2$ and $\mathrm{CA} 3$ areas and in Dentate Gyrus (DG) (Trivedi et al., 1998; Hervieu et al., 2001; Marcus et al., 2001; Cluderay et al., 2002), suggesting that OXs may play a crucial role in the functions involving the hippocampus, as evidenced in learning paradigms after intracerebroventricular (ICV) injections of OX-A (Jaeger et al., 2002; Telegdy and Adamik, 2002; Aou et al., 2003). OXs released in the hippocampus by hypothalamus neurons may be directly implicated in the control of hippocampal excitability since: 1) ICV injection of OXs in rats is followed by behavioural seizure activity (Ida et al. 1999), and 2) application of OX-A to hippocampal slices modulates the balance between GABAergic and glutamatergic neurotransmissions (Selbach et al. 2004), the dysregulation of which is a characteristic feature of epilepsy (Bernard et al., 1997; Andre et al., 2001). Thus, OXs may also be involved in epileptogenesis, which is a sequence of biochemical, anatomical and electrophysiological changes that leads to recurrent spontaneous seizures in epilepsy, and that occurs following neurological insults or disorders, such as status epilepticus (SE).

Using calibrated reverse transcriptase $(R T)$ and real time polymerase chain reaction (PCR), we evidenced for the first time within the hippocampus that prepro-OX mRNA was expressed in basal conditions and increased during epileptogenesis provoked by pilocarpine-induced status epilepticus (Pilo-SE). This expression correlated with OX-B synthesis in cell bodies resembling interneurons and 
astrocytes. Concomitantly, expression of OXs decreased at both mRNA and protein levels in hypothalamus neurons of rats having experienced Pilo-SE.

\section{Results, 3.}

\section{Study 1: Effect of Pilo-SE on body weight, feeding and drinking behaviours}

The main finding of this study is that we confirmed the decrease in body weight and food intake in rats having experienced Pilo-SE. At all time points examined, water intake in rats having experienced PiloSE did not differ significantly from that measured in rats treated with scopolamine and diazepam (SD) only, used to stop seizures induced by pilocarpine (not shown). By contrast, food consumption was reduced dramatically to a minimum observed 3 days following Pilo-SE (-82\% vs SD rats, $p<0.001$, Fig. $1 \mathrm{~A})$ and maximum body weight loss was noticed at day 5 post-SE $(-34.8 \%$ vs SD rats, $p<0.001$, Fig. 1B). The increase in food intake was initiated at day $5(+123.2 \%$ between days 5 and $6, p<0.05$, Fig. $1 \mathrm{~A})$, preceding the gain in body weight noticed at day $7(+14.6 \%$ between days 6 and $7, p<0.05$, Fig. 1B). From day 7 to 14 , rats having experienced Pilo-SE exhibited hyperphagia compared to SDtreated rats (Fig. 1A). However, mean body weight values following Pilo-SE were always below those measured in SD-treated rats throughout the period examined (21 days post-SE), even though the difference was no more statistically significant from day 12 (Fig. 1B).

\section{Study 2: Effect of Pilo-SE on prepro-OX mRNA expression}

The main finding of this study is that prepro-OX mRNA was detected in the hippocampus and that prepro-OX mRNA levels changed in opposite ways in the hypothalamus and the hippocampus following Pilo-SE. In addition to the hypothalamus, prepro-OX mRNA was detected in the hippocampus following RT-real time PCR. No amplification was obtained when reverse transcriptase was omitted from the reaction mix (not shown), excluding the possibility of genomic DNA amplification. Furthermore, sequencing of the cDNA fragment obtained revealed $100 \%$ homology with prepro-OX cDNA sequence (GenBank: AF041241) of the rat, thus confirming the specificity of the amplification product. The number of copies of prepro-OX cDNA detected in basal conditions was $\sim 50$ fold lower in the hippocampus as compared to the hypothalamus $(15,000 \pm 2,000$ and $731,000 \pm 125,000$ copies, respectively). In the hypothalamus, prepro-OX mRNA levels decreased in rats having experienced Pilo-SE, the minimum observed being reached 1 day post-SE $(-55.6 \%, p<0.01)$, levels similar to 
controls being recovered at day 3 post-SE (Fig. 2). In the hippocampus, prepro-OX mRNA levels were also affected following Pilo-SE, but in an opposite way to that observed in the hypothalamus. A significant increase was observed as soon as 1 day post-SE $(+125 \%, p<0.001)$, maintained at a plateau until day 3, control values being recovered at day 7 (Fig. 2). In situ hybridization using a DIGlabeled prepro-OX riboprobe allowed to confirm the localisation of prepro-OX mRNA containing neurons organized bilaterally and symmetrically in the lateral $(\mathrm{LH})$ and posterior $(\mathrm{PH})$ hypothalamic areas and in the perifornical nucleus (PeF) (Fig. 3A). Nevertheless, this technique was not sufficiently sensitive to detect the presence of prepro-OX mRNA containing cell bodies in the hippocampus (Fig. 3B), even following Pilo-SE. Indeed, based on quantitative RT-PCR data, the number of prepro-OX mRNA copies found in the hippocampus at day 3 post-SE was still 10 times lower than that determined at day 1 post-SE in the hypothalamus.

\section{Study 3: Effect of Pilo-SE on prepro-OX, OX-A and OX-B distribution}

The main finding of this study is that OX expression was dramatically decreased in hypothalamus neurons following Pilo-SE, while OX-B expression was increased in the hippocampus within both neurons and astrocytes.

\section{Specificity of the antibodies used}

The polyclonal antibody used to detect OX-B was obtained from a 19 mer peptide mapping near the C-terminus of human OX-B (78-96 AA; Santa Cruz) and its specificity was tested by using preincubations with OX-B blocking peptide and recombinant mouse prolactin and bombesin. Although the possibility of a non-specific immunostaining cannot be completely eliminated, the antibody used has shown a good specificity. Immunostaining was decreased in a concentration-dependent manner with OX-B blocking peptide whereas immunoreactive staining was not affected after preincubation with $1-10 \mu \mathrm{M}$ recombinant mouse prolactin and bombesin, as illustrated in the hippocampus at day 3 postSE (Fig. 4A-D). The specificity of OX-A antibody was not verified because OX-A immunolabelling was strictly identical with the one previously described (de Lecea et al., 1998; Peyron et al., 1998; Sakurai et al., 1998).

\section{OX-A and OX-B immunoreactivity of control rats}

In control rats, OX-A and OX-B immunoreactive (IR) cell bodies were abundantly found within the lateral hypothalamus and the perifornical nucleus (OX-B: Fig. 5A; OX-A: Fig. 6A), while they were 
sparsely distributed in the posterior hypothalamic area. Distribution of prepro-OX IR cell bodies correlated with OX-A and OX-B IR cell bodies (not shown). A less intensive staining for OX-B was also observed in cell bodies of numerous regions, including layers 2-3 and 5 of the neocortex, the piriform cortex and the amygdaloid complex (not shown). OX-B IR cell bodies were equally found in the stratum oriens (SO), the stratum pyramidale (SP) and the stratum radiatum (SR) in the CA2-CA3 (Fig. $7 A$ ) and CA1 regions of the hippocampus (not shown). The number of OX-B containing cells counted in the hippocampus at IA $+6.20 \mathrm{~mm}$ (Paxinos and Watson 1998) was $16 \pm 3$ in SO, $39 \pm 10$ in SP and $17 \pm 5$ in SR. OX-A was never detected in cell bodies within these regions as illustrated in the hippocampus (Fig. 7C).

A prominent network of varicose OX-A and OX-B IR fibers was observed within the hypothalamus (OX-B: Fig. 5A; OX-A: Fig. 6A), the paraventricular thalamic nucleus (PVT) (OX-B: Fig. 5D; OX-A: Fig. 6D), and the amygdaloid complex (not shown). In the dorsal hippocampus, few OX-A and OX-B IR fibers were found located in the SO, SP and SR in the CA2-CA3 regions (OX-B: Fig. 7A; OX-A: Fig. 7C) and CA1 region in the Ammon's horn, in the hilus of the DG and in the area fasciola cinerea (not shown). Prepro-OX was rarely observed in both fibers and proximal processes of hypothalamus neurons (not shown).

\section{Alteration of OX-A and OX-B immunoreactivity in the hypothalamus and the paraventricular thalamic nucleus following Pilo-SE:}

In the $\mathrm{LH}$ and the PeF, counts of OX-A and OX-B containing neurons revealed no difference at all times examined following Pilo-SE. Cells counts of OX-A containing cells were $30 \pm 7$ at day 2 post-SE $(n=4)$ vs $32 \pm 3$ in controls $(n=2 ; P>0.05)$ and $21 \pm 9$ at day 4 post-SE $(n=4)$ vs. $25 \pm 6$ in controls $(n=$ 2; $P>0.05)$ (Figs $6 A-C)$. Cells counts of OX-B containing cells were $34 \pm 5$ at day 2 post-SE $(n=4)$ vs $29 \pm 6$ in controls $(n=2 ; P>0.05)$ and $23 \pm 8$ at day 4 post-SE $(n=4)$ vs $36 \pm 7$ in controls $(n=2$; $P>0.05$ ) (Figs. 5A-C). The density of both OX-A and OX-B IR fibers decreased significantly at day 2 post-SE vs controls (Table 1; OX-B: Figs. 5A, B; OX-A: Figs. 6A, B), where labelling appeared to be disorganised, and culminating at day 4 post-SE (Table 1, OX-B: Fig. 5C; OX-A: Fig. 6C).

In the PVT, a substantial decrease in the density of both OX-A and OX-B IR fibers was observed at day 2 post-SE vs controls (Table 1, OX-B: Figs. 5D, E, OX-A: Figs. 6D, E). The density of OX-B IR fibers tended to recover the pattern observed in controls at day 4 post-SE (Table 1, Fig. 5F) whereas OX-A labelling was lower (Table 1, Fig. 6F). 


\section{Alteration of OX-A and OX-B immunoreactivity in the hippocampus following Pilo-SE}

The quantitative analysis revealed that the density of OX-A and OX-B IR fibers did not change significantly in the SO, SP and SR of the hippocampus throughout epileptogenesis (data not shown), as illustrated at 3 days post-SE vs controls (OX-B: Figs 7A, B; OX-A: Figs 7C, D). Nevertheless, we observed a significant increase in OX-B containing cells in the SO (117 \pm 13 vs $16 \pm 3$ in controls, $n=$ 4; $P<0.001)$, SP $(123 \pm 24$ vs $39 \pm 10$ in controls, $n=4 ; P<0.001)$ and $S R(366 \pm 91$ vs $17 \pm 5$ in controls, $\mathrm{n}=4 ; \mathrm{P}<0.001$ ) of $\mathrm{CA} 3-\mathrm{CA} 2$ (Figs. 7A, B) and CA1 regions of the hippocampus. Prepro-OX (not shown) and OX-A were not detected in cell bodies within these regions following Pilo-SE (Figs. 7C, D). Double-labelling studies using OX-B antibody in combination with NeuN or GFAP antibody showed that OX-B immunoreactivity was present in neurons and astrocytes within the whole hippocampal formation at day 3 post-SE (Figs. 8A, B). All the differences observed following Pilo-SE were specific to the development of SE, and could not be the result of scopolamine and diazepam treatments used to stop SE. Indeed, SD-treated rats exhibited a pattern of immunoreactivity for prepro-OX, OX-A and OX-B similar to control rats (not shown).

\section{Discussion, 4.}

Until recently, it was commonly agreed that the hypothalamus was the only source of OXs synthesis in the brain (de Lecea et al., 1998; Peyron et al., 1998; Sakurai et al., 1998). Our results extend the recent observations that OXs could be present in cell bodies outside from the hypothalamus (Ciriello et al., 2003) and highlight the possibility that synthesis of OXs could occur within the hippocampus, by showing, using quantitative RT-PCR: 1) a local presence of prepro-OX mRNA in basal conditions, and 2) an up-regulation of this transcript following Pilo-SE. Hence, we detected OX-B-like immunoreactivity in numerous cell bodies resembling interneurons and astrocytes throughout the hippocampus following Pilo-SE. These results, by evidencing that OXs could be differentially regulated between the hypothalamus and the hippocampus following Pilo-SE, suggest that the decrease of prepro-OX mRNA levels in hypothalamus neurons may support the reduction of food intake, while the increase of preproOX mRNA levels in the hippocampus may facilitate increased excitability of hippocampal neurons during epileptogenesis.

Reduction of food intake following Pilo-SE, that we have demonstrated here to be maximum at day 3 
post-SE, was associated with a profound alteration of OX synthesis in hypothalamus neurons. Indeed, the density of OX-A and OX-B IR fibers was greatly decreased not only in brain areas receiving projections from orexinergic hypothalamus neurons, as clearly evidenced in the PVT, but also in the hypothalamus. The decreased density of OX-A and OX-B IR fibers may result from the death of some hypothalamus neurons, from an alteration of the axonal targeting of both peptides or from a reduced expression of the prepro-OX gene. Here, the dramatic decrease in prepro-OX mRNA levels to a minimum observed at day 1 post-SE and the unaltered OX cell number in the hypothalamus throughout epileptogenesis argues that only a reduced expression of OXs has caused the depletion of OX-A and OX-B peptides in fibers of hypothalamus neurons. However, it is noteworthy that the altered depletion of OX-A and OX-B peptides in fibers of orexinergic neurons spared those innervating the hippocampus. This result suggests that targeting of OXs in fibers of hypothalamus neurons is precisely controlled and depends of the brain area innervated. The correlation that we evidence here between reduced OX expression in hypothalamus neurons and decreased food consumption is in agreement with the observation that intracerebroventricular injection of either OX-A or OX-B increases food consumption (Sakurai et al., 1998; Haynes et al., 1999). Taken together, these results strongly suggest that regulating OX expression in hypothalamus neurons is a key mechanism in the control of feeding behaviour. These correlations are further reinforced at the mRNA level since 1) prepro-OX mRNA is highly down-regulated in rats exhibiting reduced appetite for food following Pilo-SE, and 2) food deprivation is followed in rats by the up-regulation of prepro-OX mRNA levels (Sakurai et al., 1998; Karteris et al., 2005).

The development of highly sensitive and quantitative methods, such as calibrated RT and real time PCR, to both detect and measure any alteration in specific transcripts, made it possible to locate prepro-OX mRNA in the hippocampus. We determined that the number of prepro-OX mRNA copies in $500 \mathrm{ng}$ of total RNA in the hippocampus was $\sim 50$-fold less elevated than in the hypothalamus in basal conditions. This result may explain why prepro-OX mRNA remained undetectable in the hippocampus using colorimetric in situ hybridization, even after its level increased by 2.5 -fold through 3 days after Pilo-SE. However, such an increase in prepro-OX mRNA in the hippocampus was sufficient to elevate OX-B synthesis above detection threshold in diverse cell populations, including pyramidal neurons, interneurons and astrocytes. OX-A could not be evidenced in these cells, in spite of the fact that both peptides are derived from the same precursor (prepro-OX) by proteolytic cleavage (Sakurai et al., 
1998). Even if we cannot completely rule out the possibility that the antibody used recognized other targets than OX-B, pre-incubation of the antibody with the peptide sequence used for immunization decreased in a dose-dependant manner the signal obtained in the hippocampus, while pre-incubations with prolactin and bombesin failed to reduce the intensity of the immunolabeling. Previous data have provided evidence that neurons only labeled for OX-B were also identified in others brain regions including the central nucleus of the amygdala and the anterior lateral subnucleus of the bed nucleus of the stria terminalis (Ciriello et al., 2003). As suggested by these authors, lack of OX-A detection in the hippocampus might be explained by the absence of the proteolytic enzyme for the production of OX-A and/or by the selective clearance of OX-A by degrading enzymes.

We initially postulated that OXs originating from hypothalamus neurons may facilitate increased excitability of hippocampal neurons during epileptogenesis, since prior studies reported the implication of OXs in the modulation of neuronal excitability within the hippocampus and in the behavioural seizure activity in rats (Aou et al., 2003; Ida et al., 1999, Selbach et al., 2004). However, instead of an increased presence of OXs originating from the hypothalamus following Pilo-SE, our study shows that the density of OX-A and OX-B immunopositive fibers remained stable in the hippocampus. By contrast, the number of OX-B expressing cells dramatically and transiently increased in the hippocampus following Pilo-SE, as a consequence of the activation of the gene encoding OXs. Whereas OXs synthesized in the hypothalamus are distributed in all compartments (cell bodies, dendrites and axons) of hypothalamus neurons, we noticed that OX-B synthesized in hippocampal cells was restricted to the cell bodies. This observation led us to suggest that OX-B produced in the hippocampus in basal conditions may be released locally to exert a paracrine/autocrine control on neuronal excitability. Such a role may also be played by both interneurons and astrocytes during Piloinduced epileptogenesis. Such an action could be mediated by $O X_{1} R$ and $O X_{2} R$, the specific receptors for OX-A and B, detected within the hippocampus (Trivedi et al., 1998; Hervieu et al., 2001; Marcus et al., 2001; Cluderay et al., 2002). Although OX-A was shown to be from 5 to 100 -fold more potent than OX-B in calcium mobilization studies using CHO cells (Sakurai et al., 1998; Smart et al., 1999; Langmead et al., 2004), binding studies resulted in contradictory results in the same transfected cellular model. Indeed, OX-B was shown to have even higher affinity than OX-A in $\mathrm{CHO}$ or neuroblastoma cells expressing native $\mathrm{OX}_{1} \mathrm{R}$ (Wieland et al., 2002). Moreover, Rouet-Benzineb et al. (2004) found that OX-A and OX-B suppressed cell growth identically in a cell line expressing $\mathrm{OX}_{1} \mathrm{R}$ 
only. Therefore, in our model, the neuronal excitability could be mediated at both pre- and postsynaptic sites through both $\mathrm{OX}{ }_{1} \mathrm{R}$ and $\mathrm{OX}_{2} \mathrm{R}$. Presynaptic orexinergic excitatory actions have been demonstrated on prefrontal thalamocortical synapses (Lambe and Aghajanian, 2003) and in laterodorsal tegmental neurons (Burlet et al., 2002). At a post-synaptic level, excitatory actions of OXB have been detected in basal forebrain cholinergic neurons (Eggermann et al., 2001), in histaminergic neurons of the tuberomammilary nucleus (Bayer et al., 2001; Eriksson et al., 2001), in sublayer $6 \mathrm{~b}$ cortical neurons (Bayer et al., 2004) and in serotonin neurons of the dorsal raphe nucleus (Brown et al., 2002). It is thus likely that locally synthesized OX-B supports increased excitability of hippocampal neurons in the early stages of Pilo-induced epileptogenesis. To date, the lack of specific $\mathrm{OX}_{2} \mathrm{R}$ antagonist prevents to verify further the role played by OX-B following Pilo-SE. In addition to a role in excitability modulation, OX-B synthesized in the hippocampus may also play a role in neuronal apoptosis following Pilo-SE (Henshall and Simon, 2005) which is a major event during brain development and maturation and also in neurodegenerative diseases (Lossi and Merighi, 2003). Indeed, Oxs acting at $\mathrm{OX}_{1} \mathrm{R}$ have been shown to induce apoptosis acting at native $\mathrm{OX} 1 \mathrm{R}$ in colon cancer and neurobastoma cells (Rouet-Benzineb et al, 2004).

In conclusion, the detection of distinct clusters of neurons and astrocytes containing OX-B in the hippocampus at day 3 following Pilo-SE led us to suggest that this peptide may be involved in neuronal plasticity during the early stages of epileptogenesis and that the hypothalamus is not the only source of OXs throughout the central nervous system at least in pathophysiological conditions. Further studies will be necessary to fully discern whether the ectopic orexinergic expression in the hippocampus induces a pro- or an anti-epileptic effect.

\section{Experimental Procedure}

\section{Animals}

Male Sprague-Dawley rats $(220 \pm 19 \mathrm{~g})$ from Harlan (France) were housed for 4 weeks before treatments in groups of five under controlled environmental conditions (lights on from 6.00 to 18.00, $23^{\circ} \mathrm{C} \pm 1^{\circ} \mathrm{C}$ and free access to food and water). All experiments were performed in accordance with the guidelines of the French Ministry of Agriculture (87/848) and the European Community (86/609/EEC). The day of the experimental procedures (induction of epileptogenesis), rats were 
transferred to individual cages and kept isolated throughout the experiments. Epileptogenesis was induced in rats following Pilo-SE (Turski et al., 1983). Pilocarpine hydrochloride (Sigma) was injected intraperitoneally (IP) at a dose of $300 \mathrm{mg} / \mathrm{kg}$ (Pilo-treated rats). Methylscopolamine nitrate $(1 \mathrm{mg} / \mathrm{kg})$ was injected subcutaneously (SC) $30 \mathrm{~min}$ prior to pilocarpine in order to minimize peripherical cholinergic effects. Rats entered into SE $22 \pm 2 \mathrm{~min}$ after the injection of pilocarpine and seizures were stopped 3 hrs after SE onset with an IP injection of $10 \mathrm{mg} / \mathrm{kg}$ diazepam (Valium $®$, Roche). Scopolamine-Diazepam (SD)-treated rats received a SC injection of methylscopolamine nitrate (1 $\mathrm{mg} / \mathrm{kg}$ ), followed $30 \mathrm{~min}$ later by an IP injection of $0.9 \%$ Sodium Chloride solution and then $3 \mathrm{~h}$ later, by an IP injection of $10 \mathrm{mg} / \mathrm{kg}$ diazepam. Naïve rats (control rats) did not receive any treatment and were used to determine the potential combinatory effects of SD injections on gene expression.

\section{Study 1: Effect of Pilo-SE on body weight, feeding and drinking behaviours}

To study the consequences of the Pilo-SE on the general conditions of the rats, body weights and preweighted rat food and water were monitored each day at 9:00 am during 21 days following Pilo-SE (day 0 ) (Pilo rats $n=14$ up to day $5, n=9$ at day $6, n=7$ at day 7 and beyond). Values were compared with those obtained from SD-treated rats $(n=4)$.

\section{Study 2: Effect of Pilo-SE on prepro-OX mRNA expression}

Reverse Transcriptase real time Polymerase Chain Reaction (RT-real time PCR)

Animals were sacrificed after the onset of SE following a lethal injection of pentobarbital $(250 \mathrm{mg} / \mathrm{kg})$ and the hippocampus was rapidly removed and frozen at $t=8 h$ (Pilo $n=5, S D n=5$ ), $t=1$ day (Pilo $n=6$, SD $n=4$ ), $t=2$ days (Pilo $n=6, S D n=5$ ), $t=3$ days (Pilo $n=8, S D n=5$ ) and $t=7$ days (Pilo $n=3, S D n=5$ ). The hypothalamus was collected at $\mathrm{t}=8 \mathrm{~h}, \mathrm{t}=1$ day and $\mathrm{t}=3$ days after SE. Both brain structures were collected in naïve rats, sacrificed at $t=0$ (controls $n=5$ ).

Total RNAs were extracted with Tri-reagent LS (Euromedex) and genomic DNA was removed after DNase I digestion (RNAse Free DNAse Set, QIAgen). PCR amplifications were performed with reaction in which the reverse transcriptase was omitted to allow for assessment of genomic DNA contamination of the RNA and results revealed the absence of amplified fragment. Messenger RNAs, contained in $500 \mathrm{ng}$ hippocampal or hypothalamic total RNAs were then reverse transcribed with the reverse transcriptase RNase $\mathrm{H}$ minus (Promega) using oligod(T) $)_{15}$, in the presence of $80 \mathrm{pg}$ of a 
synthetic external and non-homologous poly(A) Standard RNA (SmRNA) to normalize the reverse transcription reaction of mRNAs of biological samples (Morales and Bezin, 2004); World Patent number 2004/092414 A12004). cDNAs obtained from the reverse-transcription of prepro-OX mRNA were quantified by real time PCR performed on the LightCycler ${ }^{\circledR}$ System (Roche Diagnostics) using the QuantiTect SYBR ${ }^{\circledR}$ Green PCR Kit (Qiagen). Both reverse (5'-CAGACACCATGAACCTTCCT-3') and forward (5'-TGGTTACCGTTGGCCTGAAG-3') primers (GenBank accession no. AF041241) generate a 274 bp PCR fragment which was confirmed by sequencing. Results obtained for preproOX mRNA were normalized against the SmRNA.

In situ hybridization (ISH)

Animals were deeply anesthetized (lethal IP injection of pentobarbital at $250 \mathrm{mg} / \mathrm{kg}$ ) and were then perfused at $30 \mathrm{~mL} / \mathrm{min}$ through the ascending aorta with $60 \mathrm{~mL}$ of phosphate buffered saline (PBS, $0.1 \mathrm{M}, \mathrm{pH} 7.4)$ followed by $300 \mathrm{~mL}$ of chilled $4 \%$ paraformaldehyde (PFA) in PB (0.1 M, pH 7.4). The brains were post-fixed for $2 \mathrm{~h}$ in the same fixative at $4^{\circ} \mathrm{C}$, transferred to $25 \%$ sucrose in $\mathrm{PB}$ at $4^{\circ} \mathrm{C}$, frozen in isopentane at $-40^{\circ} \mathrm{C}$ and then stored at $-80^{\circ} \mathrm{C}$ until further use. Coronal sections were performed with a cryostat (thickness of $40 \mu \mathrm{m}$ ) at anatomical planes from interaural (IA) $7.40 \mathrm{~mm}$ to $4.84 \mathrm{~mm}$ according to the rat brain atlas (Paxinos and Watson 1998). A 274 bp segment of rat cDNA encoding Leu28-Ala119 of prepro-OX was generated by conventional PCR and subcloned into a pGEM-T easy plasmid (Promega). Digoxygenin (DIG)-labelled sense and anti-sense riboprobes were generated with T7 and SP6 RNA polymerases, respectively, using the MEGAscript kit (Ambion). ISH protocol was performed on free floating brain tissue sections of rats sacrificed at day 3 post-SE (pilo $n=2$, control $n=2$ ) as already described in details (Tongiorgi et al. 1998), with slight modifications. Briefly, prior to hybridization, slices were post-fixed 2 hours in 4\% PFA in PB (0.1 M, pH 7.4) and were permeabilized with $2.3 \%$ sodium meta-periodate (Sigma) in $\mathrm{H}_{2} \mathrm{O}$ at $\mathrm{RT}$ for $5 \mathrm{~min}$. The sections were incubated in $1 \%$ sodium borohydride (Sigma) in $0.1 \mathrm{M}$ Tris- $\mathrm{HCl}$ buffer $\mathrm{pH} 7.5$ at $\mathrm{RT}$ for $10 \mathrm{~min}$ and were digested with $2 \mu \mathrm{g} / \mathrm{mL}$ proteinase $\mathrm{K}$ (Roche) at $4^{\circ} \mathrm{C}$ for $10 \mathrm{~min}$ and washed twice in PBST at RT for 5 min. After digestion, the tissue sections were fixed in 4\% PFA in PB at RT for 5 min. In situ hybridization was carried overnight at $55^{\circ} \mathrm{C}$ with the hybridization solution containing the DIG-labeled riboprobes $(0.5 \mathrm{ng} / \mathrm{\mu L})$ and $50 \%$ dionized formamide, 10\% dextran sulfate, 1x Denhardt's, $20 \mathrm{mM}$ Tris$\mathrm{HCl}, 300 \mathrm{mM} \mathrm{NaCl}, 5 \mathrm{mM}$ EDTA, $0.125 \mathrm{ng} / \mathrm{mL}$ denatured salmon sperm DNA. After a series of 
washes in $0.1 \mathrm{X}$ saline sodium citrate (SSC), $0.1 \%$ Tween 20 at $60^{\circ} \mathrm{C}$ for $15 \mathrm{~min}$, sections were incubated for $30 \mathrm{~min}$ with $20 \mu \mathrm{g} / \mathrm{mL}$ RNAse A (Qiagen) at $37^{\circ} \mathrm{C}$. Slices were washed three times in $2 \mathrm{x}$ SSC, twice in PBS $0.1 \mathrm{M}$ for $15 \mathrm{~min}$ and then were processed for immunodetection with an anti-DIG antibody $F(a b)$ fragment (Roche) diluted 1:1000 in 1X blocking reagent (Roche) at RT for $1 \mathrm{~h}$. Sections were incubated in developing buffer containing $1 \mathrm{mM}$ Levamisol at RT for $15 \mathrm{~min}$ and finally incubated overnight at $30^{\circ} \mathrm{C}$ in a chromogen solution composed by the developing buffer containing nitro blueterazolium (NBT) (Roche) and 5-bromo-4-chloro-3-indolyl-phosphate (BCIP) (Roche). Sections were washed three times in PBS $0.1 \mathrm{M}$, mounted on a glass slide (SuperFrost Plus), dehydrated and defatted in graded ethanols and xylene and then mounted in DPX (Fluka).

\section{Study 3: Effect of Pilo-SE on prepro-OX, OX-A and OX-B distribution}

Immunohistochemistry was performed for prepro-OX, OX-A and OX-B using immunohistochemistry on adjacent free-floating fixed brain tissue sections of rats sacrificed at $8 \mathrm{~h}$ (Pilo $n=4, S D n=2$ ), 1 day (Pilo $n=4, S D n=2$ ), 2 days (Pilo $n=4, S D n=2$ ), 3 days (Pilo $n=4, S D n=2$ ) and 4 days (Pilo $n=4, S D n=2$ ) after Pilo-SE. After rinses in PBS and permeabilization in PBS containing $0.3 \%$ triton X100 (PBS-T), sections were preincubated for $2 \mathrm{~h}$ at room temperature (RT) in $2 \%$ Normal Donkey Serum in PBS-T (PBS-T-D). Incubations with primary antibodies were then performed at $4^{\circ} \mathrm{C}$ for $48 \mathrm{~h}$, using either a polyclonal goat anti-OX-A antibody (1:1,000; sc-8070; Santa-Cruz Biotechnology), a polyclonal goat anti-OX-B antibody (1:1,000; sc-8071; Santa-Cruz Biotechnology) or a polyclonal rabbit anti-preproOX antibody (1:250; AB3096; Chemicon), diluted in PBS-T-D. For chromogenic reaction, sections were washed in PBS-T and were incubated for $24 \mathrm{~h}$ at $4^{\circ} \mathrm{C}$, either with a biotinylated donkey anti-goat $\lg$ (1:10,000; AP180B, Chemicon) or a biotinylated donkey anti-rabbit IgG (1:5,000; 711-066-152, Jackson ImmunoResearch) diluted in PBS-T-D. Sections were then incubated for 5 min in $1 \% \mathrm{H}_{2} \mathrm{O}_{2}$, rinsed in PBS and then incubated for $1 \mathrm{~h} 30$ min at RT with avidin biotin peroxydase (1:500; Vectastain Elite ABC kit, Vector) diluted in PBS. The sections were reacted with $0.4 \mathrm{mM}$ 3', 3-diaminobenzidine (DAB, Sigma Fast) for $5 \mathrm{~min}$, then mounted, dehydrated and coverslipped. The staining results were observed with a video camera 3CCD (DXC-930P; Sony) connected to a microscope (Leitz Diaplan). In order to characterize cell types, fluorescent double immunostaining was performed using the polyclonal goat anti-OX-B antibody described above $(1: 1,000)$ with either a mouse anti-NeuN $(1: 1,000$, MAB 377, Chemicon) or a rabbit anti-GFAP (Glial Fibrillary Acid Protein, 1:3000; AB 5804; Chemicon) 
antibody to detect neurons and astrocytes, respectively. Sections were washed in PBS-T before being exposed to donkey anti-mouse IgG (1:500; Alexa-488, A-21202; Molecular probes), donkey anti-rabbit IgG (1:500; Alexa-488; A-21206; Molecular Probes) or donkey anti-goat IgG (1:500; Alexa-633; A21082; Molecular Probes) antibodies. Specificity controls of the OX-B antiserum used were done by preincubating the primary antiserum with $1-10 \mu \mathrm{M}$ of either OX-B blocking peptide (78-96 AA; sc-8071 P, Santa-Cruz Biotechnology), or recombinant mouse prolactin (1445-PL RnDSystems) or bombesin (H-2155, Bachem, Switzerland). Sections were mounted, dehydrated and coverglassed with Prolong Gold Antifade reagent (P 36930; Molecular Probes). Images captured using a TCS SP2 confocal microscopy system (Leica) were imported into Adobe Photoshop 8.0.1 (Adobe Systems, San Jose, USA) for further editing.

\section{Neuronal counts and measurements of density of fibers}

Sections immunostained for OX-A and OX-B were observed under a light microscope (Diaplan; Leitz), and images were captured with a video camera 3CCD (DXC-930P; Sony) coupled to an image analysis system (Visilog ${ }^{\circledR}$ 6.0; Noesis). The system allows to scan at magnification 10X adjacent fields throughout the brain structures (LH, PeF, dorsal hippocampus and PVT) and to reconstruct a single image composed of a mosaic of the digitized adjacent fields. These structures were selected at IA $+6.20 \mathrm{~mm}$ (Paxinos and Watson 1998). Neurons expressing OX-A and OX-B were counted within the surface area of the LH and the PeF occupied by OX-A and OX-B immunopositive cell bodies at both sides and were expressed as mean cells \pm SEM. Cells expressing OX-B were measured within the SO (measurement window: 50,000 $\mathrm{m}^{2}$ ) SP (measurement window: 50,000 $\mu \mathrm{m}^{2}$ ) and SR (measurement window: $170,000 \mu \mathrm{m}^{2}$ ) of the Ammon's Horn of the hippocampus at both sides and were expressed as mean cells \pm SEM. The density of fibers expressing OX-A and OX-B was determined in measurement windows, the surface area of which is indicated for each structure, and expressed as the surface area occupied by the specific immunolabeling within the measurement window. The structures analyzed were the PVT (measurement window: 190,000 $\mathrm{m}^{2}$ ) and the LH (measurement window: $280,000 \mu \mathrm{m}^{2}$ ). In controls, mean densities of OX-A and OX-B fibers were expressed as $\mu \mathrm{m}^{2}$ of fibers $/ \mu \mathrm{m}^{2}$ of measurement windows. Mean densities of OX-A and OX-B fibers following Pilo-SE were expressed as the percentage of variations vs controls. 


\section{Data analysis}

All results were presented as mean \pm S.E.M. Group comparisons were performed following two-way analysis of variance (ANOVA II) (factor 1: treatment, factor 2: time), using a post-hoc Fisher's LSD test.

\section{Acknowledgments}

We thank B. Smatti and Y. Tourneur from the "Centre Commun de Quantimétrie" of Université Claude Bernard Lyon 1 for their helpful assistance in confocal microscopy analysis. This study was supported by the Centre National de la Recherche Scientifique (CNRS) and the University Claude Bernard Lyon 1, France. 


\section{References}

Andre, V., Marescaux, C., Nehlig, A., Fritschy, J. M., 2001. Alterations of hippocampal GAbaergic system contribute to development of spontaneous recurrent seizures in the rat lithium-pilocarpine model of temporal lobe epilepsy. Hippocampus 11, 452-468.

Aou, S., Li, X. L., Li, A. J., Oomura, Y., Shiraishi, T., Sasaki, K., Imamura, T., Wayner, M. J., 2003. Orexin-A (hypocretin-1) impairs Morris water maze performance and CA1-Schaffer collateral long-term potentiation in rats. Neuroscience 119, 1221-1228.

Bayer, L., Eggermann, E., Serafin, M., Saint-Mleux, B., Machard, D., Jones, B., Muhlethaler M., 2001. Orexins (hypocretins) directly excite tuberomammillary neurons. Eur. J. Neurosci. 14, 1571-1575.

Bayer, L., Serafin, M., Eggermann, E., Saint-Mleux, B., Machard, D., Jones, B. E., Muhlethaler, M., 2004. Exclusive postsynaptic action of hypocretin-orexin on sublayer $6 \mathrm{~b}$ cortical neurons. J. Neurosci. $24,6760-6764$.

Bernard, C., Hirsch, J., Ben-Ari, Y., 1997. Recepteurs excitateurs glutamatergiques et epilepsie du lobe temporal. Revue Neurologique 153, 14-24.

Brown, R. E., Sergeeva, O. A., Eriksson, K. S., Haas H. L., 2002. Convergent excitation of dorsal raphe serotonin neurons by multiple arousal systems (orexin/hypocretin, histamine and noradrenaline). J. Neurosci. 22, 8850-8859.

Burlet, S., Tyler, C. J., Leonard, C. S., 2002. Direct and indirect excitation of laterodorsal tegmental neurons by Hypocretin/Orexin peptides: implications for wakefulness and narcolepsy. J. Neurosci. 22, 2862-2872.

Chemelli, R. M., Willie, J. T., Sinton, C. M., Elmquist, J. K., Scammell, T., Lee, C., Richardson, J. A., Williams, S. C., Xiong, Y., Kisanuki, Y., Fitch, T. E., Nakazato, M., Hammer, R. E., Saper, C. B., Yanagisawa, M., 1999. Narcolepsy in orexin knockout mice: molecular genetics of sleep regulation. Cell 98, 437-451.

Ciriello, J., Rosas-Arellano, M. P., Solano-Flores, L. P., de Oliveira, C. V., 2003. Identification of neurons containing orexin-B (hypocretin-2) immunoreactivity in limbic structures. Brain Res. 967, 123131.

Cluderay, J. E., Harrison, D. C. , Hervieu G. J., 2002. Protein distribution of the orexin-2 receptor in the rat central nervous system. Reg. Peptides 104, 131-144.

Date, Y., Ueta, Y., Yamashita, H., Yamaguchi, H., Matsukura, S., Kangawa, K., Sakurai, T., Yanagisawa, M., Nakazato, M., 1999. Orexins, orexigenic hypothalamic peptides, interact with autonomic, neuroendocrine and neuroregulatory systems. Proc. Natl. Acad. Sci. USA 96, 748-753. 
de Lecea, L., Kilduff, T. S., Peyron, C., Gao, X., Foye, P. E., Danielson, P. E., Fukuhara, C., Battenberg, E. L., Gautvik, V. T., Bartlett, F. S., Frankel, W. N., van den Pol, A. N., Bloom, F. E., Gautvik, K. M., Sutcliffe, J. G., 1998. The hypocretins: hypothalamus-specific peptides with neuroexcitatory activity. Proc. Natl. Acad. Sci. USA 95, 322-327.

Eggermann, E., Serafin, M., Bayer, L., Machard, D., Saint-Mleux, B., Jones, B. E., Muhlethaler, M., 2001. Orexins/hypocretins excite basal forebrain cholinergic neurones. Neuroscience 108, 177-181.

Eriksson, K. S., Sergeeva, O., Brown, R. E., Haas, H. L., 2001. Orexin/hypocretin excites the histaminergic neurons of the tuberomammillary nucleus. J. Neurosci. 21, 9273-9279.

Greco, M. A., Shiromani, P. J., 2001. Hypocretin receptor protein and mRNA expression in the dorsolateral pons of rats. Brain Res. Mol. Brain Res. 88, 176-182.

Hagan, J. J., Leslie, R. A., Patel, S., Evans, M. L., Wattam, T. A., Holmes, S., Benham, C. D., Taylor, S. G., Routledge, C., Hemmati, P., Munton, R. P., Ashmeade, T. E., Shah, A. S., Hatcher, J. P., Hatcher, P. D., Jones, D. N., Smith, M. I., Piper, D. C., Hunter, A. J., Porter, R. A., Upton N., 1999. Orexin A activates locus coeruleus cell firing and increases arousal in the rat. Proc. Natl. Acad. Sci. USA 96, 10911-10916.

Haynes, A. C., Jackson, B., Overend, P., Buckingham, R. E., Wilson, S., Tadayyon, M., Arch, J. R., 1999. Effects of single and chronic intracerebroventricular administration of the orexins on feeding in the rat. Peptides 20, 1099-1105.

Henshall, D. C., Simon, R. P., 2005. Epilepsy and apoptosis pathways. J. Cereb. Blood Flow. Metab. 25, 1557-72.

Hervieu, G. J., Cluderay, J. E., Harrison, D. C., Roberts, J. C., Leslie, R. A., 2001. Gene expression and protein distribution of the orexin-1 receptor in the rat brain and spinal cord. Neuroscience 103, 777-797.

Ida, T., Nakahara, K., Katayama, T., Murakami, N., Nakazato, M., 1999. Effect of lateral cerebroventricular injection of the appetite-stimulating neuropeptide, orexin and neuropeptide $Y$, on the various behavioral activities of rats. Brain Res. 821, 526-529.

Jaeger, L. B., Farr, S. A., Banks, W. A., Morley J. E., 2002. Effects of orexin-A on memory processing. Peptides 23, 1683-1688.

Karteris, E., Machado, R. J., Chen, J., Zervou, S., Hillhouse, E. W., Randeva, H. S., 2005. Food deprivation differentially modulates orexin receptor expression and signaling in rat hypothalamus and adrenal cortex. Am. J. Physiol. Endocrinol. Metab. 288, E1089-1100.

Lambe, E. K., Aghajanian, G. K., 2003. Hypocretin (orexin) induces calcium transients in single spines postsynaptic to identified thalamocortical boutons in prefrontal slice. Neuron 40, 139-150. 
Langmead, C. J., Jerman, J. C., Brough, S. J., Scott, C., Porter, R. A., Herdon, H. J. 2004. Characterisation of the binding of $[3 \mathrm{H}]-\mathrm{SB}-674042$, a novel nonpeptide antagonist, to the human orexin-1 receptor. Br. J. Pharmacol. 141, 340-346.

Lin, L., Faraco, J., Li, R., Kadotani, H., Rogers, W., Lin, X., Qiu, X., de Jong, P. J., Nishino, S., Mignot E., 1999. The sleep disorder canine narcolepsy is caused by a mutation in the hypocretin (orexin) receptor 2 gene. Cell 98, 365-376.

Lossi, L., Merighi, A., 2003. In vivo cellular and molecular mechanisms of neuronal apoptosis in the mammalian CNS. Prog. Neurobiol., 69, 287-312.

Marcus, J. N., Aschkenasi, C. J., Lee, C. E., Chemelli, R. M., Saper, C. B., Yanagisawa, M., Elmquist, J. K., 2001. Differential expression of orexin receptors 1 and 2 in the rat brain. J. Comp. Neurol. 435, 6-25.

Nishino, S., Ripley, B., Overeem, S., Lammers, G. J., Mignot E., 2000. Hypocretin (orexin) deficiency in human narcolepsy. Lancet 355, 39-40.

Paxinos, G., Watson, C., 1998. The rat brain in stereotaxic coordinates, Fourth Edition. Academic Press.

Peyron, C., Tighe, D. K., van den Pol, A. N., de Lecea, L., Heller, H. C., Sutcliffe, J. G., Kilduff, T. S. 1998. Neurons containing hypocretin (orexin) project to multiple neuronal systems. J. Neurosci. 18, 9996-10015.

Peyron, C., Faraco, J., Rogers, W., Ripley, B., Overeem, S., Charnay, Y., Nevsimalova, S., Aldrich, M., Reynolds, D., Albin, R., Li, R., Hungs, M., Pedrazzoli, M., Padigaru, M., Kucherlapati, M., Fan, J., Maki, R., Lammers, G. J., Bouras, C., Kucherlapati, R., Nishino, S., Mignot, E., 2000. A mutation in a case of early onset narcolepsy and a generalized absence of hypocretin peptides in human narcoleptic brains. Nat. Med. 6, 991-997.

Rouet-Benzineb, P., Rouyer-Fessard, C., Jarry, A., Avondo, V., Pouzet, C., Yanagisawa, M., Laboisse, C., Laburthe, M., Voisin, T. 2004. Orexins acting at native $\mathrm{OX}_{1}$ receptor in colon cancer and neuroblastoma cells or at recombinant $\mathrm{OX}_{1}$ receptor suppress cell growth by inducing apoptosis. J. Biol. Chem. 279, 45875-45886.

Sakurai, T., Amemiya, A., Ishii, M., Matsuzaki, I., Chemelli, R. M., Tanaka, H., Williams, S. C., Richardson, J. A., Kozlowski, G. P., Wilson, S., Arch, J. R., Buckingham, R. E., Haynes, A. C., Carr, S. A., Annan, R. S., McNulty, D. E., Liu, W. S., Terrett, J. A., Elshourbagy, N. A., Bergsma, D. J., Yanagisawa M., 1998. Orexins and orexin receptors: a family of hypothalamic neuropeptides and G protein-coupled receptors that regulate feeding behavior. Cell 92, 573-585.

Selbach, O., Doreulee, N., Bohla, C., Eriksson, K. S., Sergeeva, O. A., Poelchen, W., Brown, R. E., 
Haas H. L., 2004. Orexins/hypocretins cause sharp wave- and theta-related synaptic plasticity in the hippocampus via glutamatergic, gabaergic, noradrenergic, and cholinergic signaling. Neuroscience $127,519-528$

Shirasaka, T., Nakazato, M., Matsukura, S., Takasaki, M., Kannan, H., 1999. Sympathetic and cardiovascular actions of orexins in conscious rats. Am. J. Physiol. Regul. Integr. Comp. Physiol. 277, R1780-1785.

Smart, D., Jerman, J. C., Brough, S. J., Rushton, S. L., Murdock, P. R., Jewitt, F., Elshourbagy, N. A., Ellis, C. E., Middlemiss, D. N., Brown, F., 1999. Characterization of recombinant human orexin receptor pharmacology in a Chinese hamster ovary cell-line using FLIPR. Br. J. Pharmacol.;128, 1-3.

Telegdy, G., Adamik, A., 2002. The action of orexin A on passive avoidance learning. Involvement of transmitters. Reg. Peptides 104, 105-110.

Tongiorgi, E., Righi, M., Cattaneo, A., 1998. A non-radioactive in situ hybridization method that does not require RNAse-free conditions. J. Neurosci. Method 85, 129-139.

Trivedi, P., Yu, H., MacNeil, D. J., Van der Ploeg, L. H., Guan, X. M., 1998. Distribution of orexin receptor mRNA in the rat brain. FEBS Letters 438, 71-75.

Turski W. A., Cavalheiro, E. A., Schwarz, M., Czuczwar, S. J., Turski, L., 1983. Limbic seizures produced by pilocarpine in rats: behavioural electroencephalographic and neuropathological study. Behav. Brain Res. 9, 315-335.

Wieland, H. A., Soll, R. M., Doods, H. N., Stenkamp, D., Hurnaus, R., Lammle, B., Beck-Sickinger, A. G. 2002. The SK-N-MC cell line expresses an orexin binding site different from recombinant orexin 1type receptor. Eur. J. Biochem. 269, 1128-1135.

Yamada, H., Okumura, T., Motomura, W., Kobayashi, Y., Kohgo, Y., 2000. Inhibition of food intake by central injection of anti-orexin antibody in fasted rats. Biochem. Biophysic. Res. Com. 267, 527-531. 


\section{Figure legends}

Fig.1 Food intake (A) and body weight (B) monitoring following Pilo-SE reveals a rapid and drastic reduction in food consumption until day 5, the increase in food intake observed between days 5-6 preceding the significant gain in body weight observed at day 7 . Note that rats having experienced Pilo-SE exhibited hyperphagia from day 7 to day 14 post-SE, and that the difference in body weight between these rats and Scopolamine-Diazepam (SD) controls was not significant by day 12 . $\boldsymbol{\Delta}$ :Difference in pilocarpine-treated rats at one time point as compared to the prior one. $\boldsymbol{\Delta} p<0.05$;

$\Delta \Delta \Delta<<0.001$. *: Difference at a given time point between Pilo-treated and SD-treated rats. ${ }^{*} p<0.05 ;{ }^{* *} p<0.01 ;{ }^{* * *} p<0.001$. Pilo rats: $n=14$ up to day $5, n=9$ at day $6, n=7$ at day 7 and beyond. SD rats: $n=4$.

Fig.2 Levels of expression of prepro-OX mRNA in the hippocampus and in the hypothalamus following Pilo-SE by RT-real time PCR. Messenger RNAs were reverse transcribed in the presence of a synthetic external and non-homologous poly(A) Standard RNA (SmRNA) to normalize the reverse transcription reaction. In the hypothalamus, prepro-OX mRNA levels decreased in rats having experienced Pilo-SE, the minimum observed being reached at day 1 post-SE $(-55.6 \%, p<0.01)$, levels similar to controls being recovered at day 3 post-SE. In the hippocampus, the induction of prepro-OX mRNA levels contrasts with the inhibition observed in hypothalamus neurons following Pilo-SE. Values are expressed as percentage of control rats. ${ }^{* *} p<0.01 ;{ }^{* * *} p<0.001$.

Fig. 3 Bright-field photomicrographs in the perifornical nucleus of the hypothalamus and the CA3-CA2 regions of the hippocampus at day 3 post-SE in rat brain sections hybridized with digoxigenin-labeled riboprobes for prepro-OX mRNA. In situ hybridization technique allowed to confirm the localisation of prepro-OX mRNA containing neurons in the PeF (A) but was not sufficiently sensitive to detect the presence of prepro-OX mRNA containing cell bodies in the CA3-CA2 regions of the hippocampus (B) even following Pilo-SE. Scale bar: $100 \mu \mathrm{m}(\mathrm{A}-\mathrm{B})$.

Fig. 4 Confocal images of the CA3 region of the hippocampus at day 3 post-SE labelled with OX-B antiserum in the in the absence $(\mathrm{A})$ and in the presence of $10 \mu \mathrm{M}$ of either OX-B blocking peptide (the 19 mer fragment used to obtain the antibody) (B) or recombinant mouse prolactin (C) and bombesin 
(D). OX-B immunoreactivity was strongly decreased when $10 \mu \mathrm{M}$ OX-B blocking peptide was incubated with OX-B antibody (B) while immunolabeling was not affected when $10 \mu \mathrm{M}$ of either recombinant mouse prolactin $(C)$ or bombesin $(D)$ was added. Scale bar: $15 \mu \mathrm{m}(A-D)$.

Fig. 5 Immunohistochemical detection of OX-B in the lateral hypothalamus and the paraventricular thalamic nucleus in control rats and in rats having experienced Pilo-SE. In the LH, counts of OX-B containing neurons revealed no difference at day $2(B)$ and at day 4 post-SE $(C)$ vs controls $(A)$. The density of OX-B IR fibers decreased significantly at day 2 post-SE (B) where labelling appeared to be disorganised and culminating at day 4 post-SE (C). In the PVT, a substantial decrease in the density of OX-B IR fibers was observed at day 2 post-SE (E) vs controls (D) which tended to recover the pattern observed in controls at day 4 post-SE $(F)$. Scale bar: $250 \mu \mathrm{m}(\mathrm{A}-\mathrm{F})$.

Fig. 6 Immunohistochemical detection of OX-A in the lateral hypothalamus and the paraventricular thalamic nucleus in control rats and in rats having experienced Pilo-SE. In the LH, counts of OX-A containing neurons revealed no difference at day 2 (B) and day 4 post-SE (C) vs controls (A). The density of OX-A IR fibers diminished significantly at day 2 post-SE (B), culminating at day 4 post-SE (C). In the PVT, the density of OX-A IR fibers decreased at day 2 post-SE (E) vs controls (D) and was lower at day 4 post-SE (F). Scale bar: $250 \mu \mathrm{m}(\mathrm{A}-\mathrm{F})$.

Fig. 7 Immunohistochemical detection of OX-B and OX-A in the hippocampus. OX-B was detected in control rats (A) and at day 3 post-SE (B). A significant increase in OX-B containing cells was observed in the stratum oriens $(\mathrm{SO})$, the stratum pyramidale $(\mathrm{SP})$ and the stratum radiatum (SR) of the CA3CA2 region of the hippocampus (B). Nevertheless, OX-A labeling was not detected in these regions both in control rats (C) and at day 3 post-SE (D).Scale bar: A,B,C,D $100 \mu \mathrm{m}$

Fig. 8 Double-immunostainings were performed using either a mouse anti-NeuN or a rabbit anti-GFAP antibody (to characterize neurons and astrocytes, respectively) in combination with the anti-OX-B antibody in the stratum radiatum of CA3 region of the hippocampus at day 3 post-SE. OX-B appears as red fluorescence and both NeuN and GFAP appear as green fluorescence. Confocal microscopy images of the rat hippocampus double labelled with OX-B antiserum and NeuN showed that OX-B 
immunoreactivity was present in neurons localised in the stratum radiatum of the CA3 region of the hippocampal formation (A). Straight arrow indicates representative neuron with coincident NeuN (green fluorescence) and OX-B labeling (red fluorescence). OX-B immunoreactivity was equally present in astrocytes $(B)$ within this region. Crossed arrow indicates representative astrocyte with coincident GFAP (green fluorescence) and OX-B labeling (red fluorescence). Scale bar: $10 \mu \mathrm{m}(\mathrm{A}-\mathrm{B})$. 
Table 1: Altered density of OX-A and OX-B fibers in the lateral hypothalamus and the PVT following Pilo-SE.

\begin{tabular}{ccc|cc} 
& \multicolumn{2}{c|}{ OX-A } & \multicolumn{2}{c}{ OX-B } \\
& Day 2 & Day 4 & Day 2 & Day 4 \\
\hline Lateral HPT & $\begin{array}{c}38 \pm 6^{*} \\
(n=4)\end{array}$ & $\begin{array}{c}-68 \pm 8^{* *} \\
(n=4)\end{array}$ & $\begin{array}{r}-41 \pm 4^{*} \\
(n=4)\end{array}$ & $\begin{array}{c}-60 \pm 7^{* *} \\
(n=4)\end{array}$ \\
\hline PVT & $\begin{array}{c}39 \pm 7^{*} \\
(n=4)\end{array}$ & $\begin{array}{c}-51 \pm 6^{* *} \\
(n=4)\end{array}$ & $\begin{array}{c}-56 \pm 5^{* *} \\
(n=4)\end{array}$ & $-8 \pm 3$ \\
& & & $(n=4)$
\end{tabular}

In controls, mean density of OX-A IR fibers expressed as $\mu \mathrm{m} 2 / \mu \mathrm{m} 2$ of measurement area was: $0.17 \pm$ 0.02 and $0.12 \pm 0.03$ in the LH and the PVT respectively. In controls, mean density of OX-B IR fibers expressed as $\mu \mathrm{m} 2 / \mu \mathrm{m} 2$ of measurement area was: $0.14 \pm 0.03$ and $0.09 \pm 0.02$ in the LH and the PVT respectively. At day 2 and day 4 post-SE, mean densities of OX-A and OX-B IR fibers are expressed as the percentage of variations vs controls. ${ }^{*} \mathrm{P}<0.05,{ }^{* *} \mathrm{P}<0.01$ vs controls. 

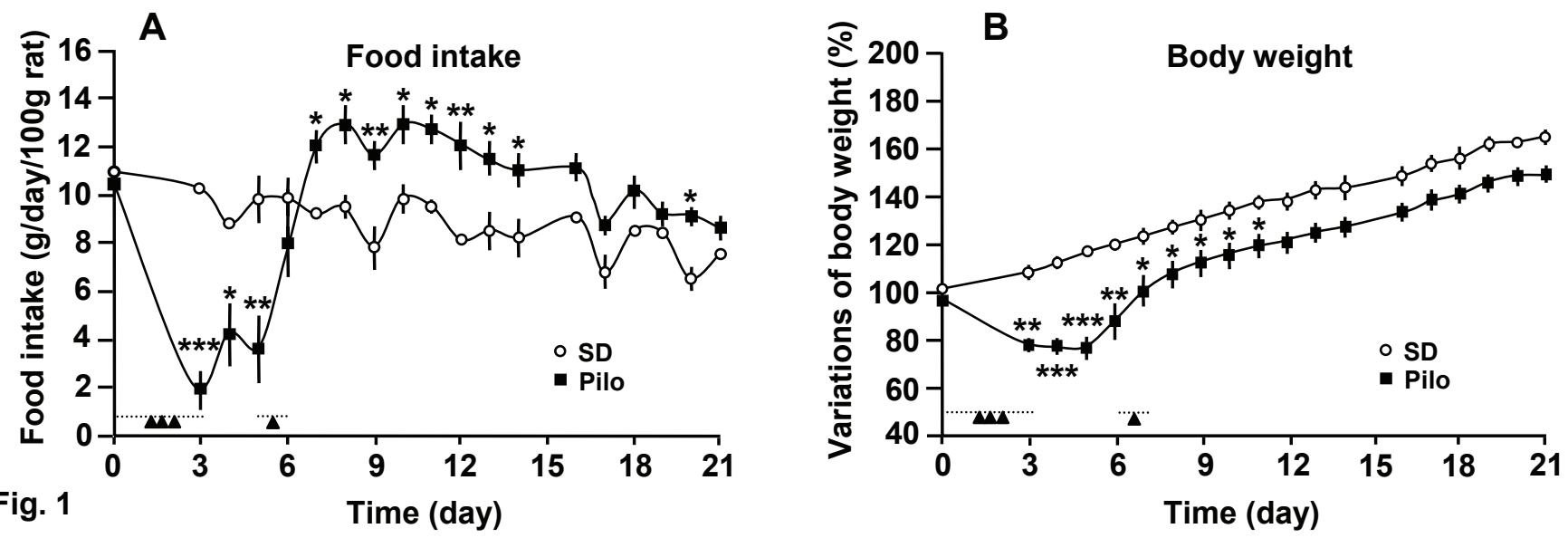


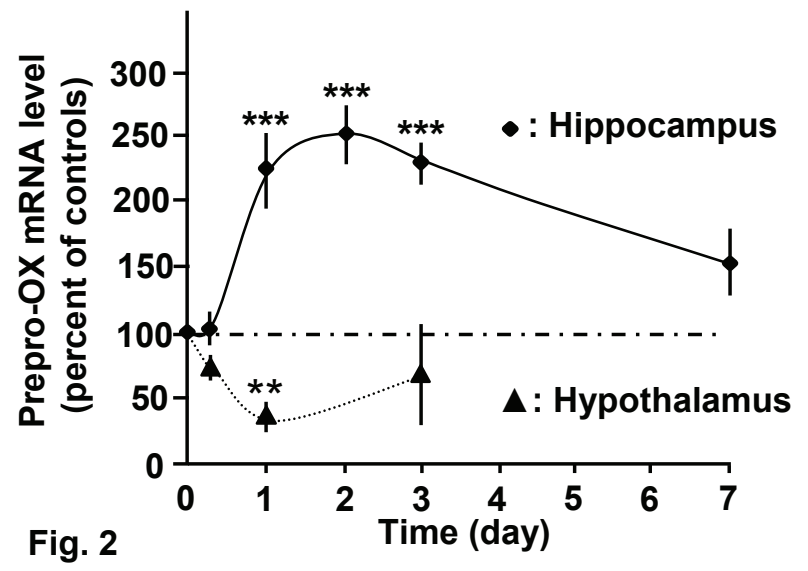




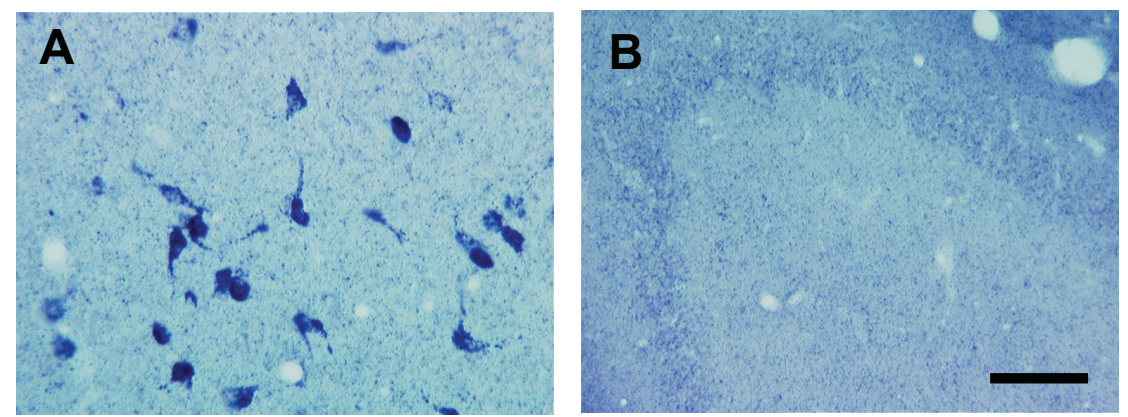

Fig.3 

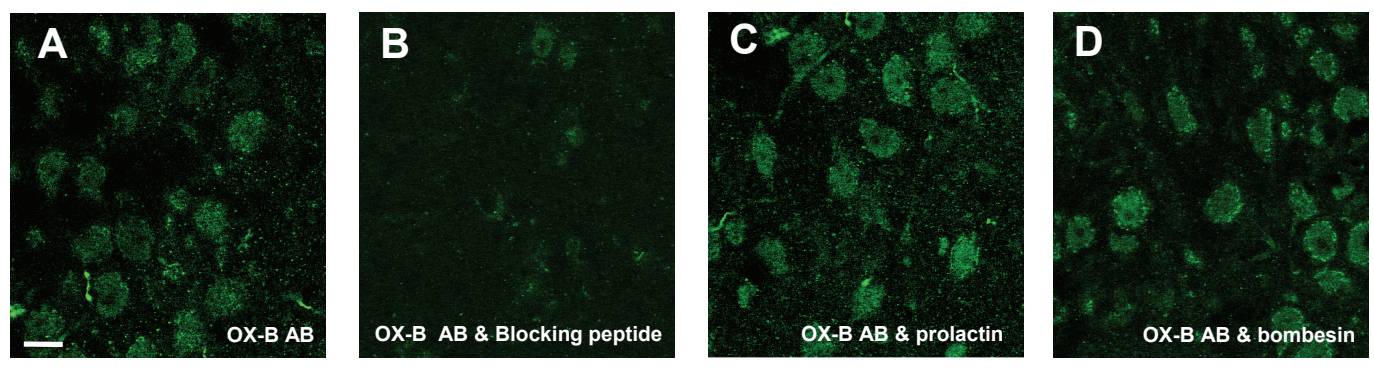

Fig.4 


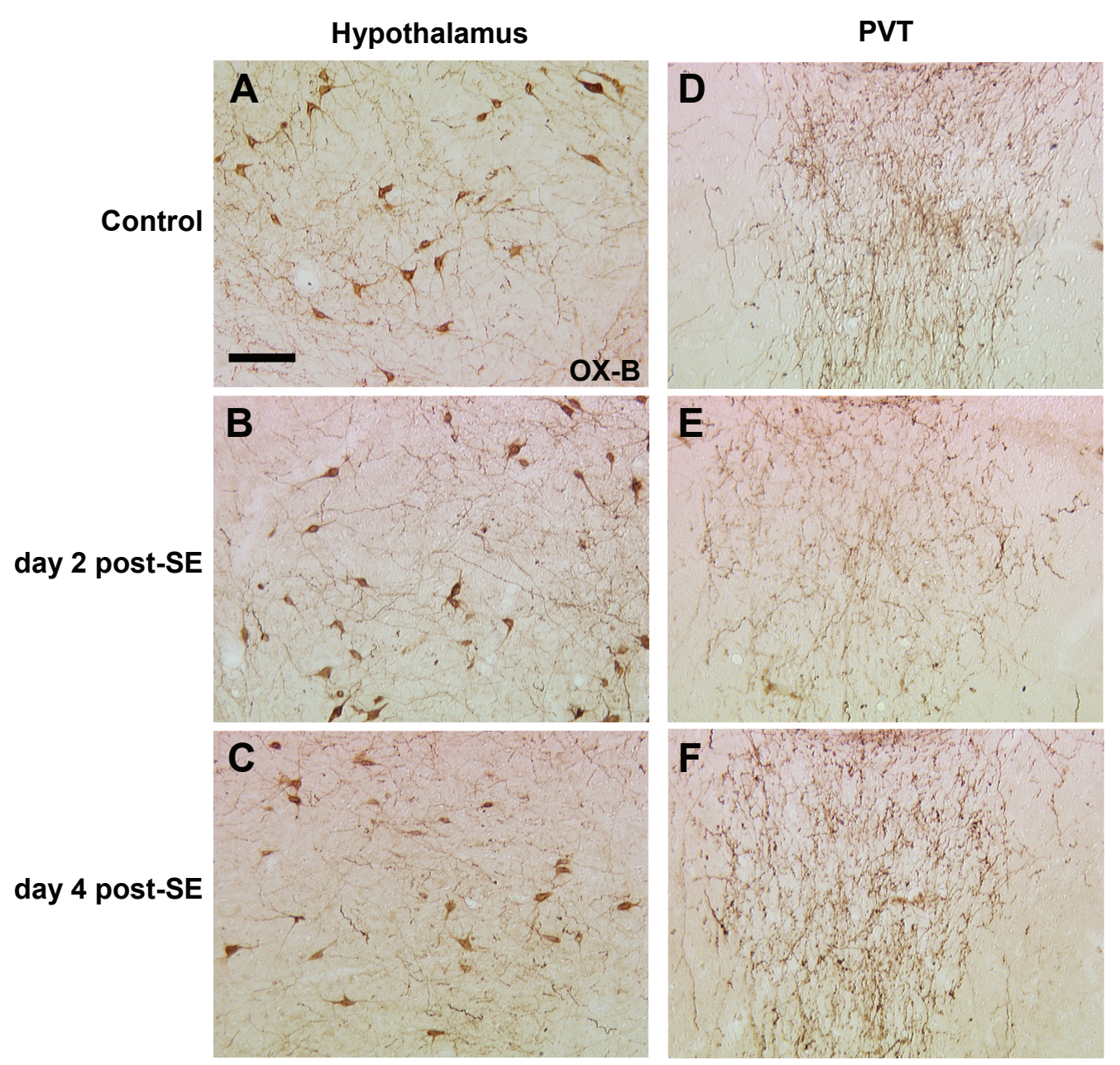

Fig. 5 


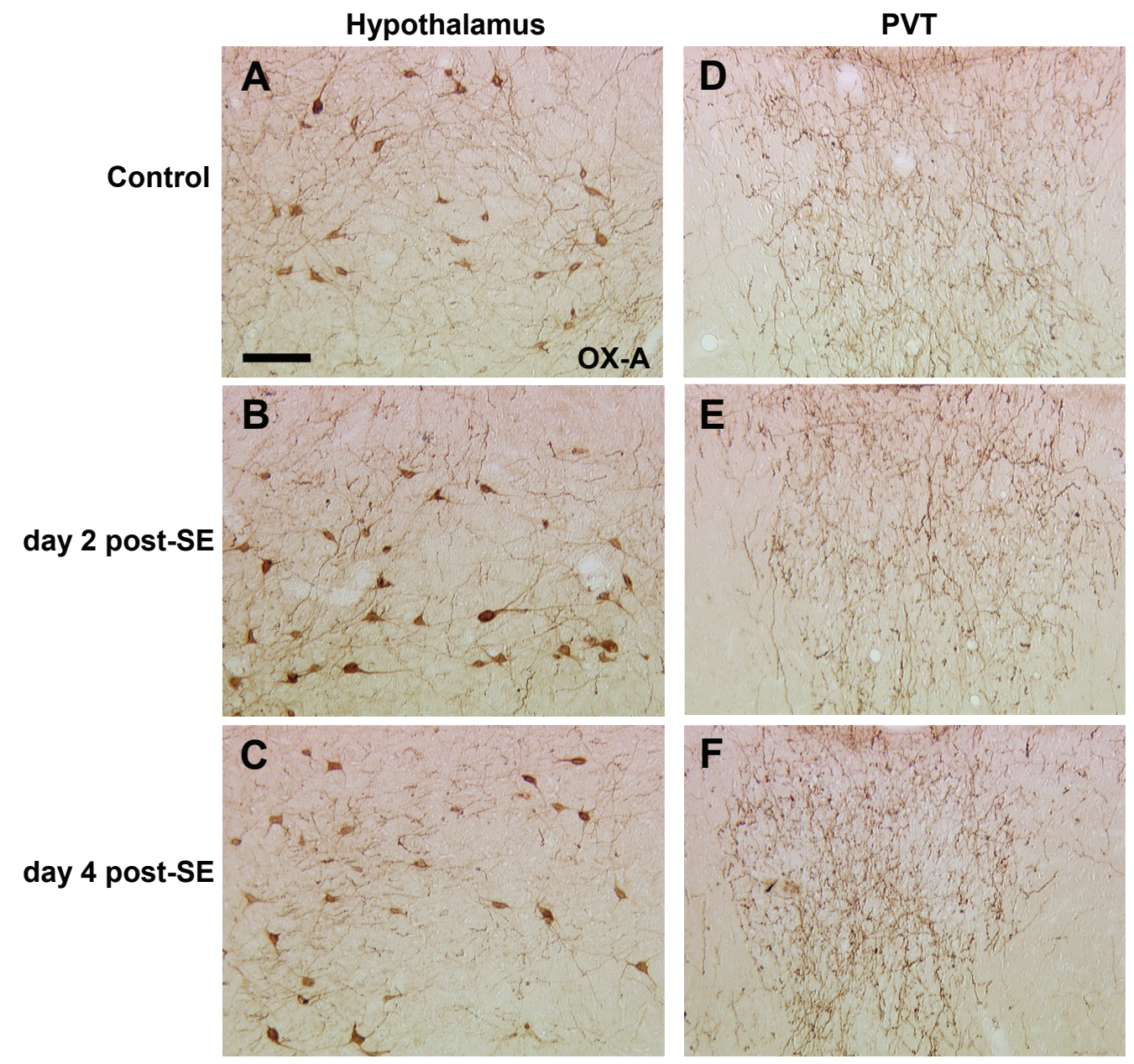

Fig. 6 
Hippocampus

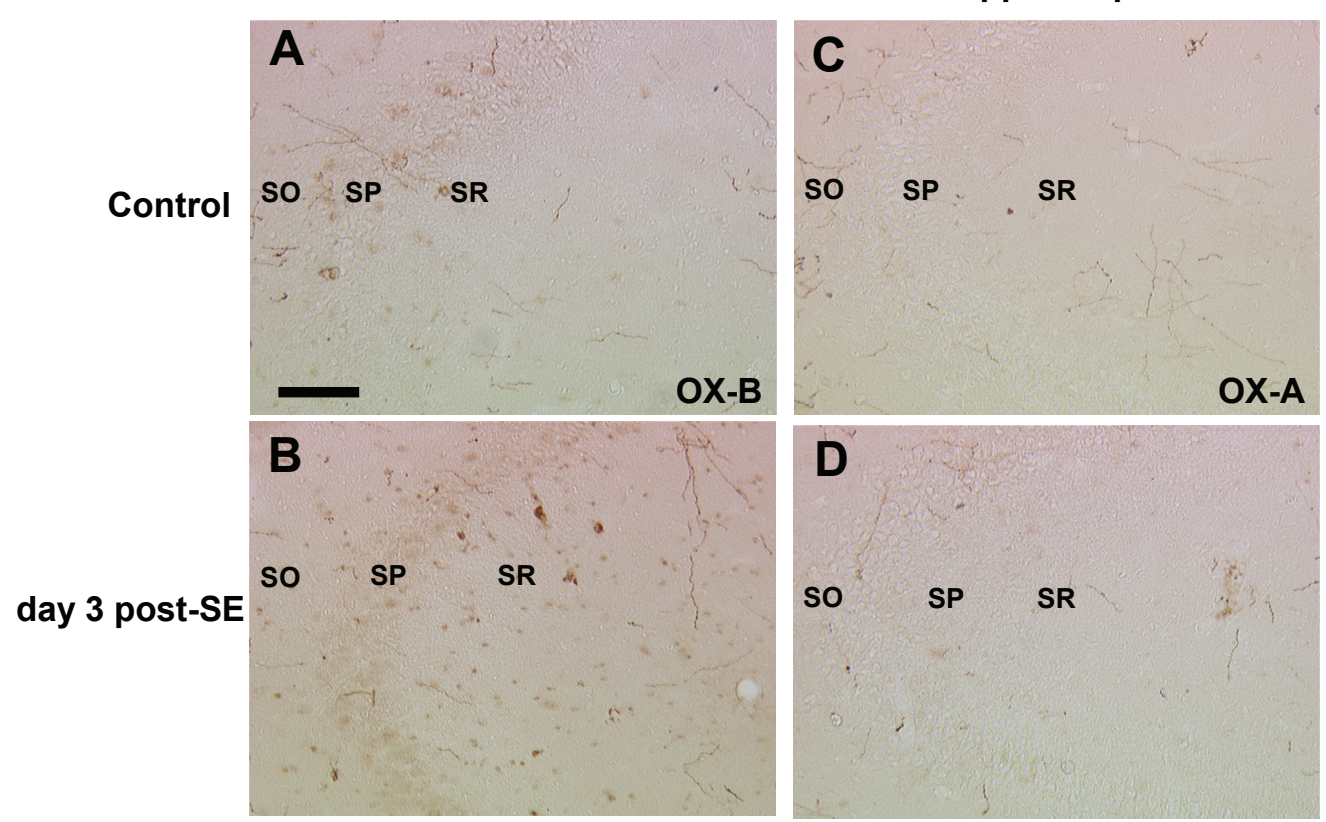

Fig. 7
Hippocampus

D

SO SP SR 


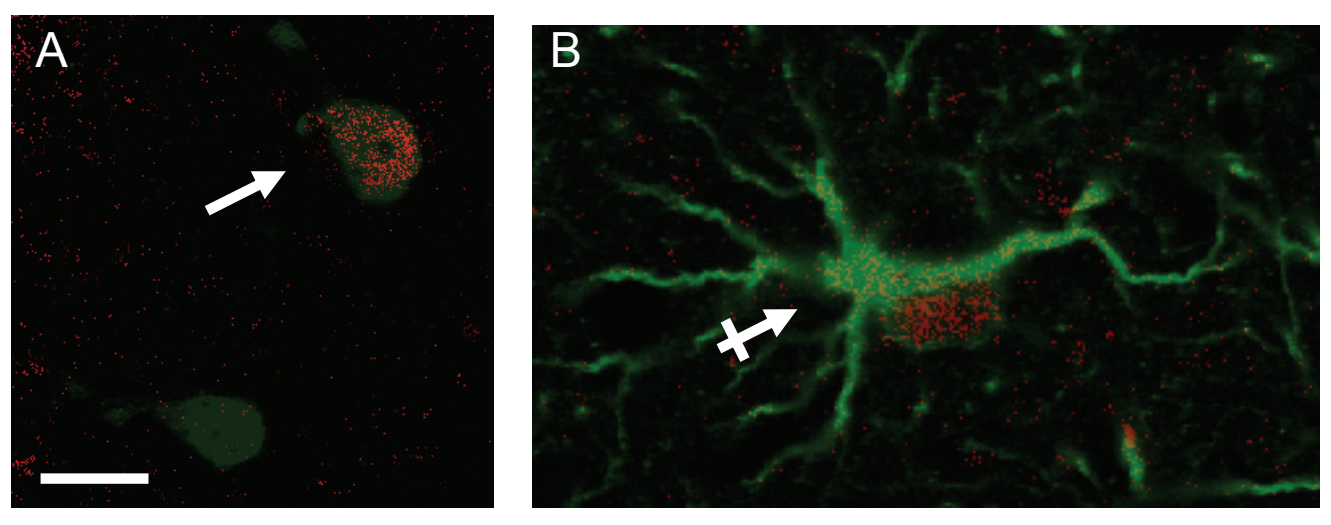

Fig. 8 